\title{
'The Holy Land of Industrialism': rethinking the Industrial Revolution
}

\author{
Joel Mokyr
}

Keynes Lecture in Economics, read 25 September 2019.

Abstract: Various explanations of Britain's economic technological leadership between 1760 and 1850 have been proposed for many decades and have dealt with many aspects of British society: politics, natural resources, and its Empire. One of the less-discussed hypotheses places the emphasis on the quality of its workforce: the most skilled workers in Britain such as engineers, instrument-makers, and millwrights. These workers were the ones who actually put into practice the innovative blueprints and models of the inventors. On the eve of the Industrial Revolution, Britain's high-skilled workers were superior to those anywhere else, and this difference was a critical element in its technological performance during the Industrial Revolution. The institution that produced this superior competence was British apprenticeship, which was the chief source of technical human capital in this age.

Keywords: Industrial Revolution, Skills, Human Capital, Apprenticeship, Institutions.

Note on the author: Joel Mokyr is Robert H. Strotz Professor of Arts and Sciences and Professor of Economics and History at Northwestern University; and Sackler Professorial Fellow, Eitan Berglas School of Economics, at the University of Tel Aviv. He was elected a Corresponding Fellow of the British Academy in 2016.

(C) The author(s) 2021. This is an open access article licensed under a 


\section{Introduction}

Some historical events are so momentous that they serve as a 'watershed' in our mental organisation of history. American history is typically divided into 'ante-bellum' and 'post-bellum' history, and of course for many years European history explicitly divided itself into 'BC' and 'AD'. The British Industrial Revolution was not an 'event', and by its traditional timing lasted for two generations, yet it can claim with some justification to be a watershed that changed economic history more than anything since the Neolithic Revolution. It was the beginning of a new world, a world of plenty in which material conditions would be unrecognisably better for the median person than for the richest and most powerful in earlier times, and a world in which work and production would never be the same again.

There are many ways of looking at the Industrial Revolution: a macroeconomic point of view (growth), an industrial organisation point of view (the rise of the factory), a demographic one (the end of the Malthusian regime), and quite a few others. The argument I am making here is that it involved a shift of the 'engine of growth' of the economy. Until the Industrial Revolution, insofar as economic growth occurred anywhere in the world, it was the result of 'Smithian growth', based on the widening of markets, the division of labour, and the gains from trade. Innovation did take place before the Industrial Revolution, of course, but, despite some spectacular advances in the Middle Ages and the early modern period, they were not frequent enough and not sufficiently encompassing to affect overall economic growth. The Industrial Revolution elevated technological progress to the role of the primary engine of the economy, and changed the entire dynamic of economic history, a 'phase transition' as it were. The main driver of encompassing economic change (because the economy changed in many more ways than just incomes) increasingly became 'useful knowledge' rather than the growth of commerce and the division of labour, though those remained central and were in turn deeply transformed by the growth of useful knowledge. While past centuries have witnessed economies grow through dual engines, technology has become the primum movens. To paraphrase Alfred North Whitehead's famous statement, the Industrial Revolution did not mark the beginning of invention, but it marked the beginning of 'the method of invention'-turning it from an occasional event to a regular and routine part of the economy.

The literature 'explaining' the Industrial Revolution is voluminous, and can be divided somewhat arbitrarily into three categories: why in the 18th century (and not, say, in the Middle Ages or during the Roman Empire); why did it start in Britain (and not, say, in France or the Netherlands); and why Europe (and not, say, China or the Ottoman Empire). In what follows, I shall discuss primarily the 'why Britain' question, 
though the timing question remains in the background. The famous statement made a quarter of a century ago by the eminent economic historian Max Hartwell that 'there was an Industrial Revolution, and it was British' (Hartwell 1990: 575) needs to be modified. While Britain was its technological and economic leader, in the end it was a European phenomenon. Many of the inventions, including for that matter the steam engine (often seen as the paradigmatic invention of the Industrial Revolution), were the result of a combination of British and Continental ingenuity. That said, by the time of the Crystal Palace Exhibition in 1851, few had any doubts about British primacy.

How to explain British precocity? Britain was far from the largest country in Europe, it was not the richest, nor the best educated. By 1700 it had political institutions that were the envy of Continental philosophes, but in and of themselves these seem inadequate as an explanation. It had built an extractive colonial Empire on three continents, and was actively engaged in the Atlantic slave and sugar trades that generated enormous profits. A rich scholarly tradition, following the seminal work of Eric Williams (1944), has linked the Atlantic trade with economic growth. ${ }^{1}$ Yet while Atlantic trade obviously accelerated commercialisation and economic growth in the West (at the expense, needless to add, of non-Europeans), it is hard to see why of all the European nations that participated in it, it would be only in Britain where it triggered an Industrial Revolution. ${ }^{2}$ Indeed, in an influential paper written only partly tongue in cheek, another eminent economic historian of the Industrial Revolution, Nicholas Crafts, maintained that it could be in large part due to chance (Crafts 1977). Yet the question of British leadership is central to our understanding of the Industrial Revolution as the central event of modern economic history. Had Britain, for some

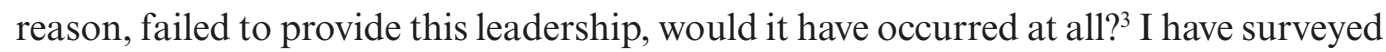
the major 'schools' elsewhere (Mokyr 2009, Kelly et al. 2021a).

In what follows, I will propose a somewhat different argument from the standard ones which, while not altogether novel, has to date not received sufficient attention and which in my view is probably the most persuasive.

\footnotetext{
${ }^{1}$ For a recent discussion of the literature on Atlantic trade, see the very useful collection in Leonard \& Pretel (2015). The most relevant essay in that collection is Knick Harley's essay (2015); he remains sceptical that the Atlantic trade would have singled out Britain to be the pioneer of the Industrial Revolution. ${ }^{2}$ As Harley points out, the British colonies in the West Indies were less productive than the French ones, and actually needed to be protected from cheaper French sugar. North America, of course, supplied raw cotton grown with slave labour, but by the time cotton became central to the Atlantic, the regions that grew it were no longer ruled by Britain.

${ }^{3}$ It may indeed be asked whether, if a triumphant Spanish Armada had succeeded in turning England into a benighted theocracy ruled by fanatical inquisitors, the Industrial Revolution would have taken place. Fairly minor rewrites of history, as imagined, for instance, in the counterfactual novel of Kingsley Amis (1976), or in an imaginative paper by Jack Goldstone (2006) might not seem far-fetched.
} 


\section{Upper Tail Human Capital}

The question of what drives technological progress must relate to the question of who drives it. On this question, classical Enlightenment writers had little doubt: progress was driven by a tiny elite of able and competent people, some of them intellectuals, physicians, applied mathematicians, and others top-rated artisans, mechanics, and engineers. Robert Hooke famously referred to them as a Cortesian Army, somewhat infelicitously comparing them to the 'success' of the eponymous Conquistador. Adam Smith and David Hume both stressed the point that, if the 'philosopher' turned their 'speculations' toward the improvements of the mechanical arts, the benefits may eventually 'descend to the meanest' people (Smith 1978: 574). Hume (1742) added that the motives of this group are 'delicate and easily' perverted and chance or unknown causes were of great importance to the 'progress of the refined arts'.

Past historiography has wisely steered away from 'Great Man Theories' of History, in which major social and economic changes were chalked up to the genius of a few superstars. But it is possible to go too far in the other direction and to ignore altogether the importance of relatively small groups. New knowledge is normally created by people who already possess the old knowledge and recognise its weaknesses and suggest how to alter and improve it. In recent years, a growing literature has recognised the significance of Upper Tail Human Capital (henceforth UTHC) in bringing about the most significant changes in past economies. If we look at the distribution of training and education through whatever means in an economy, the UTHC would include the most skilled and learned members of society. The economic impact of the UTHC depends on the content of the education. If the best trained people in society excelled in swordplay or the Talmud, their impact on economic growth would be minimal. If, on the other hand, their education emphasised 'useful knowledge' such as mechanics and practical mathematics, they could become critical in the growth of industry, engineering, and agriculture.

The economic importance of this elite group becomes particularly salient when the primary engine driving the economy gradually becomes technological progress. As long as it was primarily gains from trade, what was needed was a much larger body of merchants and their agents and employees that made trade possible. But advances in useful knowledge, while they too have many dimensions of a social and cooperative effort, require only a small elite of active agents. At least in principle, once the knowledge has been generated, the costs of sharing it and accessing it, are tolerable.

The upper tail relevant to the Industrial Revolution consisted of two overlapping groups, which we may call intellectuals and artisans. ${ }^{4}$ Much of the literature has

${ }^{4}$ The overlap consisted of a number of people who straddled the worlds of 'knowers' and 'producers'both intellectuals who could build their own instruments such as Hooke and Laplace, and artisans such as John Smeaton who, even if lacking in formal education, were well read in natural philosophy. 
focused on intellectuals (e.g., Jacob 2014, Squicciarini \& Voigtländer 2015, Dittmar \& Meisenzahl 2020). This seems perfectly reasonable from the point of view that industrialists and improving landlords often consulted natural philosophers. To be sure, in most activities, the direct practical value of what natural philosophers knew before 1800 was still limited. The crucial role of the most skilled artisans in the Industrial Revolution has been less central to the debates, with some notable exceptions (Berg 2007, Cookson 2018). Many of the paradigmatic inventions of the Industrial Revolution were, of course, made by people who by any definition would qualify as artisans. ${ }^{5}$ Others would be called 'wrights' or 'engineers' (the two groups overlap). Right below them were lesser known people who still left a historical record and can be traced (Skempton 2002, Meisenzahl \& Mokyr 2012, Howes, 2017). But these groups are the tip of a larger iceberg, a population of skilled and dexterous anonymous workers, whose abilities were above all tacit and to some extent based on mechanical intuition. Many of them were far from being intellectual or even literate, yet in terms of their mechanical competence and dexterity they clearly belonged in the upper tail of useful knowledge. The advantage of Britain was in the totality of these groups and the synergies they created.

A stubborn opinion prevalent at the time of the Industrial Revolution was that the British were good implementers and mechanics, but that they were not good inventors. ${ }^{6}$ It is hard to see where that view precisely originated, as many British inventors made great technological leaps forward in the 18th century. That said, it is still plausible that, while Britain may have had an absolute advantage in both original technological ideas and applying and improving existing ideas, it may well have had a comparative advantage in the latter. Even during the heyday of the Industrial Revolution between 1750 and 1825, Britain accounted for about 44 per cent of all 'major' inventions, as tabulated by Giovanni Gozzini (cited in Vries 2013). Inventions had to be made practical and, if possible, profitable. To do so, new equipment had not only to be built, but installed, operated, maintained, and repaired by expert craftsmen. In an age in which machinery was custom-made rather than compiled from identical parts, these operations depended on trained and experienced workers adept at handling files and chisels.

How many such artisans could reasonably qualify as being included in the upper tail? A brief back-of-the-envelope calculation might point to perhaps $2-2 \frac{1}{2}$ per cent of the labour force in manufacturing, and a lower percentage in agriculture and services - so that a national estimate of 2 per cent may not be far off the mark, even

\footnotetext{
${ }^{5}$ Among them were Thomas Newcomen and his assistant John Calley, Abraham Darby, John Kay, James Hargreaves, John Harrison, Benjamin Huntsman, Bryan Donkin, and Richard Roberts.

${ }^{6}$ This view was expressed, a century apart, by the essayist and novelist Daniel Defoe and the engineer and inventor John Farey.
} 
though the boundaries are of course arbitrary. ${ }^{7}$ It is the advantage that Britain had in having such artisans in far greater supply and of higher quality that was decisive in her leadership in the Industrial Revolution. The often-overlooked fact is that many inventions made in the centuries before the Industrial Revolution may have been sound in concept and design, but were unrealistic because of the absence of necessary workmanship and materials. ${ }^{8}$ British artisans provided major improvements in both.

\section{The role of competence}

In the centuries before the Industrial Revolution, there was considerable productivity growth among Europe's artisans. Whereas in 1500 it may be plausibly argued that in many areas, from ceramics to textiles to metalworking, Asian and Middle Eastern craftsmen could still outperform Europe's, by 1750 this gap had closed in most areas. Relying on scattered evidence, Stephan Epstein (2008: 71) has suggested considerable productivity growth due to the anonymous improvements and experimentation carried out by Europe's craftsmen, from the woollen industry to printing and clockmaking. A perfect example of this continuous improvement is provided by Kelly \& Ó Gráda (2017) who show that in the 17th century, the English watch industry experienced a decline in the real price of watches by an average of 1.3 per cent a year between 1685 and 1810, the result of an increasingly finer division of labour and learning by doing. Another example is in the small arms industry. Philip Hoffman (2015) shows the secular decline in the prices of firearms due to the growth in total factor productivity, estimating a rise in total factor productivity of pistols of 1.1 per cent a year (1556-1706) relative to a low-tech product such as spades. Karel Davids's (2008) monumental survey of technology in the Netherlands in this era finds widespread if uneven technological progress and productivity growth in a variety of industries.

Yet British artisans differed significantly from their Continental colleagues. In 18th-century France, brilliant mechanics like Abbé Nollet and Jacques de Vaucanson, two of the most interesting figures of 18th-century French Industrial Enlightenment, spent much effort in building expensive 'toys' (that is, metal ornaments and trinkets) and artifacts for the rich and the noble, and had the high society of Paris flock to their

\footnotetext{
${ }^{7}$ Between 1700 and 1840, 8,328 individuals took out at least one patent in the Patent Office. Given the great cost and difficulty of obtaining a patent in Britain before 1851, this is of course a drastic undercount of the number of those ingenious mechanics who actually made an invention themselves as opposed to those who actually had the resources to take out a patent (Hanlon 2020).

${ }^{8}$ The most famous examples are the many designs proposed by Leonardo da Vinci, none of which were built in his lifetime, but there were Cornelis Drebbel's submarine and Pascal's calculator, both of which were sound concepts that could not be scaled up.
} 
fashionable lectures (Bertucci 2017). French inventors worried about elegance and taste more than about price and cost, in sharp contrast to the sober and practical craftsmen working away in the grimy workshops of Leeds and Keighley (Cookson 2018). The difference in the careers of two inventors of screw-cutting lathes in the 1790s, the celebrated English inventor and engineer Henry Maudslay and the obscure Frenchman Senot is telling. ${ }^{9}$ On more than one occasion, French and German inventors were frustrated by the absence of interest in their inventions and the lack of competent mechanics who could turn inventions into reality. ${ }^{10}$

Contemporaries recognised the difference. In 1786, an anonymous French writer (concerned about opening free trade between Britain and France) wailed 'We have set the French workmen to grips with the English workman. It is the combat of a naked man against an armed man and it has the outcome we may expect and the victory cannot be disputed. Is no resource left to us?' (cited by Harris 1998: 412). The most prominent French political economist of his age, Jean-Baptiste Say, similarly attributed 'Britain's enormous wealth' to the 'wonderful practical skills of her adventurers in the useful application of knowledge and the superiority of her workmen'. Louis Simond, a French-born American visitor at the beginning of the 19th century observed that 'the English are great in practical mechanics, in no country in the world are there, perhaps, so many applications of that science' (Simond [1815] 1968: 123).

The precise relation between skills and technological progress is subtle. On the one hand, skilled artisans were needed to install the new equipment. On the other hand, many of the traditional skills of the artisanal world were obviously becoming obsolete through the 'de-skilling' associated with the Industrial Revolution. As mechanisation proceeded, some of the old techniques were displaced and human capital suffered from technological obsolescence. But, even within the mechanised sector, technological progress often 'front-loaded' the sophisticated technology in the sense that the ingenuity was baked into the design, and that operation and maintenance were simplified. ${ }^{11}$

\footnotetext{
${ }^{9}$ Henry Maudslay, who among others devised a screw-cutting lathe, was a successful and celebrated engineer, who trained some of the best next-generation engineers and left his sons with a prospering business. The Frenchman Senot designed a similar device a few years before Maudslay. Of Senot, revealingly, nothing else is known, not even his first name, and his machine was never built (Daumas 1972: 112).

${ }^{10}$ Samuel Smiles (1883: 220) cites an observation by Arthur Young visiting France in 1787, reporting on a Mr Lomond, described by Young as a very 'ingenious and inventive mechanic' with a string of interesting inventions, including a proto-telegraph. Smiles added that, although 'the model of the invention was actually made, it still awaited the advent of the scientific inventor ... who would embody it in a practical working form.'

${ }^{11}$ The most widely cited example of front-loading was Richard Roberts's self-acting mule, which was reputed to have been stimulated by the hard-nosed bargaining of the skilled operators (Rosenberg 1976: 118 ) and which eventually replaced highly skilled workers with more sophisticated equipment. William Lazonick (1979: 234) dates part of this front-loading to the 1790s when the larger mules became power
} 
What this points to is that, at least in those techniques in which such front-loading occurred, the importance of UTHC would be especially prominent. ${ }^{12}$

Should the UTHC also include scientists? The debate about the importance of science in the Industrial Revolution is old and quite fascinating. ${ }^{13}$ Yet it has always had the character of a glass-half-full debate. The popular notion that the Industrial Revolution was driven by 'tinkerers'-uneducated artisans, unfamiliar with the best-practice science of the time, which in any case would have done them little goodseems to be as overstated as the one that regards the Industrial Revolution as Newtonian science applied to the shopfloor (Ó Gráda 2016). Sharp lines between the sphere of abstract propositional knowledge and the mundane world of applied prescriptive knowledge are in any case hard to draw. Indeed, it was the essence of the Industrial Enlightenment that the bridges between the two spheres became wider and more numerous. Many of the most prominent 18th-century natural philosophers were deeply interested in 'the useful arts', and for good reason. The exchanges between formal propositional knowledge and technology went both ways. ${ }^{14}$ Natural philosophers, as they were known then, wrote books about metals, machines, and mines, and were consulted by industrialists and improving landowners. Some of them actually made some notable inventions - one thinks of Joseph Priestley or Claude Bertholletoften exploited by people more entrepreneurial than themselves. Some of the best industrialists were comfortable with science and tried to apply lessons they had learned from natural philosophers. Quite a few others were not, and Cormac Ó Gráda is surely right when he points out that most of the foremost inventor-entrepreneurs of the Industrial Revolution were of rather modest, artisanal origin (Ó Gráda 2016: 227).

operated (water- or steampower). Another example are the Nautical Almanacs, detailed tables that allowed sailors to calculate their longitude before Harrison's clocks were cheap enough to be made widely available. Nevil Maskelyne, the Astronomer Royal, employed highly numerate 'computers' who put together more user-friendly tables by that allowed seamen to compute with accuracy their location at sea in 30 minutes as opposed to the four hours required by the original techniques designed by Tobias Mayer (Croarken 2002).

${ }^{12}$ In a somewhat self-serving statement, the entrepreneur most widely associated with interchangeable parts, Henry Ford, stated that 'I have heard it said ... that we have taken skill out of work. We have not. We have put a higher skill into planning, management, and tool building, and the results of that skill are enjoyed by the man who is not skilled.' He distinguished sharply between two classes of workers: the skilled men who 'are the tool makers, the experimental workmen, the machinists, and the pattern makers ... The rank and file of men come to us unskilled; they learn their jobs within a few hours or a few days.' (Ford [1922], 2013: 60).

${ }^{13}$ For strongly opposing views, compare Jacob (2014) with McCloskey $(2010,2021)$.

${ }^{14} \mathrm{~A}$ recent essay has restated the mutual exchange between science and technology in this time, 'rather than considering inventions as applications of scientific knowledge, we need to consider how seemingly technical practices ... contributed to the understanding of substances [such as aerial matter and steam]' (Thébauld-Sorger 2018: 101). 
Many of them were 'plain Englishmen, without Science' as the Scottish scientist Joseph Black wrote to James Watt of Henry Cort, the inventor of the pathbreaking puddling and rolling iron-refining process. ${ }^{15}$

The debate, however, would be clearer if we kept three points in mind: first, certain advances, even if not made by scientists, depended on insights and methods acquired from experimental philosophy, which filtered down, however indirectly, to the artisans in question. Second, in the second half of the 18th century, science took an 'instrumentalist' turn, part of what J.L. Heilbron has called the 'quantifying spirit' - an emphasis on accuracy and careful measurement, focusing on the 'practical uses of numbers and system' (Heilbron 1990: 3). Finally, and perhaps most centrally, the flow of scientific input into industry and agriculture may have been relatively thin in the late 18th century, but it became an evermore powerful stream in the 19th century. Without it, the Industrial Revolution would have eventually fizzled out and become just one more efflorescence.

Yet, in spite of the growing importance of science, it does little or nothing to explain British leadership. To be sure, British scientists were an integral part of the eruption of Western science after 1750. Yet it was a multinational effort, in which Britain was a primum inter pares. Its leadership was very much concentrated in the practical and artisanal parts of UTHC, in the exceptional quality of its mechanics, its engineers, its millwrights, and its metalworkers. What counted, above all, was well summarised by the engineer Marc Brunel, who famously wrote that 'it was one thing to invent, another thing to make the invention work'. Smiles also cited a revealing letter by James Watt who wrote that 'what is the principal hindrance to erecting engines? It is always the smith work'. (Both cited in Smiles 1883: 223, 224.) The question is whether this argument, widely believed by contemporaries, can be supported by evidence, and whether we can explain the gap between Britain and the Continent. ${ }^{16}$

Two of the sources that produced the most skilled workers were mills and coal mines. The profession of the millwright began to morph into something different in the closing decades of the 18th century (MacLeod \& Nuvolari 2009, Mokyr et al. 2021). In a widely cited statement, the great 19th-century engineer William Fairbairn described the millwright of former years as an itinerant engineer and mechanic of high reputation who could 'turn, bore and forge ... was a fair arithmetician who knew something of geometry and [could] do much of the work now done by civil engineers'

\footnotetext{
${ }^{15}$ It is telling that some of those poorly educated industrialists made sure that their sons who followed them in the enterprise were better educated. Ó Gráda cites Jedediah Strutt as an entrepreneur with a 'narrow and contracted' education; but his eldest son William Strutt was model of an enlightened factory master. He was not only well educated and widely read but a skilled architect, the designer of fire-resistant buildings with a particular interest in heating engineering and a Fellow of the Royal Society.

${ }^{16}$ For examples of such opinion, see Mokyr (2009: 108-12).
} 
(Fairbairn 1861: v-vi). Anton Howes's sample of 937 specialised innovators in the period before and during the Industrial Revolution shows that more than a quarter of them were millwrights or similarly trained craftsmen such as 'mechanics' and 'engineers' (Howes 2017: 24). Some of the most accomplished inventors of the age were trained as millwrights, such as Bryan Donkin, the co-inventor of food canning and a paper making machine, Andrew Meikle, the Scottish inventor of the threshing machine, and William Murdoch, Watt and Boulton's most able employee and coinventor of gas lighting among many other things. Many lesser known but indispensable mechanics and engineers were also trained as millwrights. Collieries, similarly, were a focal industry, in which many sophisticated and dexterous artisans concentrated. Many of the pioneers of the high-pressure engine between 1800 and 1825, such as Richard Trevithick, George Stephenson, and John Blenkinsop, were trained in the mining industry. Arthur Woolf (1766-1837), one of the great engineers of his age, worked in the Cornish non-ferrous metal mines. To be sure, Britain was not the only European economy that had coal mines and water mills, but the mechanics who worked there were regarded as superior.

Skills were crucial to an economy subject to accelerating technological progress if they were not just sophisticated but agile. Technical training in Britain was not only of high quality, but it was relatively flexible. Highly skilled artisans needed to be able to adapt to the needs of different if often related occupations (Cookson 2018: 106, 126). The most telling evidence for this agility was that a full one-third of the list of innovators compiled by Anton Howes made inventions that were quite different from the specialised training and skill of the inventor and invented in a range of seemingly unrelated fields (Howes 2017: 36). High-level skills did not yet imply high levels of specialisation. As Howes put it, 'mechanical training could be applied to anything, from textile machinery to agricultural machinery to coachbuilding' (24). Moreover, such flexibility allowed for knowledge in one industry to spill over into others. Clockand watchmaking expertise was repeatedly able to solve mechanical problems in textile manufacturing, and the use of reverberatory furnaces, originally designed for glass, were adapted to the iron industry, in the form of two of the most notable advances of the Industrial Revolution: Huntsman's crucible steel (1740) and Cort's puddling process (1783).

Beyond workmanship, what the Industrial Revolution depended on was materials. The mechanics of the Industrial Revolution depended on their tools and, as Chris Evans and Alun Withey point out, without a multitude of high-quality files, punches, drill bits, saws, and dies, much of British manufacturing would not have flourished as much (Evans \& Withy 2012: 544). To make those tools, springs, and machine parts of 
sufficient quality and durability, what was needed was high-quality steel. ${ }^{17}$ Benjamin Huntsman is often credited with the crucible technique of 1740 , but many other 'boutique steel makers' were active in Sheffield in the first half of the 18th century (Evans \& Withey 2012: 538). By 1700, long before crucible steel, Britain already produced the best files in Europe (Harris 1974: 95). In other materials, too, Britain had acquired a high level of expertise that set it apart, even if some Continental countries were competitive: Wedgwood's Burslem ceramics factory is of course the most famous of these. But, even in chemical industries, the British proved unusually adept at developing and applying new insights, whatever their source: the cotton bleaching process, invented in France, was famously 'borrowed' by Boulton and Watt during their visit to France in the winter of $1786 / 87$. It was eventually made commercially practical by the Scotsman Charles Tennant, who combined Berthollet's chlorine 'bleaching liquor' with lime and upon this insight built the vast St Rollox chemical works in Glasgow after 1799. Progress was, of course, slow and halting: it took fourteen years for the Scottish chemists to turn Berthollet's invention into a truly successful industrial product (Christie 2018: 317-18).

British chemistry, like much of the Enlightenment science practised in Britain, was above all practical and directed at commercial applications. James Keir, a Scottish chemist, worked closely as a consultant to Boulton and Watt and owned Britain's most successful alkali works. Glasgow, indeed, provided the best example for that feature, in the person of William Irvine (1743-87), who did important work on thermal phenomena, the effect of light on the growth of vegetables, and the processes of large glass-making (Fox 2004). His students created the Chemical Society of Glasgow, discussing practical chemical issues. Both Scottish and English chemists left the great discoveries to Continental scientists such as Lavoisier and von Liebig; their specialty was successfully applying chemical insights originally discovered on the Continent with considerable economic gain, albeit at serious environmental cost. ${ }^{18}$

\section{Evidence for British artisanal superiority}

Apart from individual biographies, the most persuasive evidence that can be adduced to support Britain's artisanal superiority is the movement of British engineers and

\footnotetext{
${ }^{17}$ Friedrich Engels noted in 1844 (12) that, thanks to Huntsman's invention and the 'greater purity of the materials placed at its disposal, and the more perfect tools, new machinery and a minute division of labor, the metal trade of England now first attained importance'.

${ }^{18}$ James Muspratt, an Irish-born chemist, set up the first factory utilising the Leblanc soda-making process in Liverpool (later moving to St Helens), a venture that was wildly successful - much more so than in France (where the inventor committed suicide in 1806) (Gillispie 2004: 416).
} 
artisans to the Continent, where they were in high demand exactly because of their ability to install and operate equipment that embodied cutting-edge technology. It was well understood that the tacit 'knacks' (tours de main) of industry could not be readily transferred among nations. ${ }^{19}$ For the purpose of establishing a causal relationship, it is important to demonstrate that the demand for English mechanics on the Continent preceded the Industrial Revolution. Following the peace Treaty of Utrecht of 1714, British artisans, technicians, and industrial experts, especially in textile technology, moved to France (Henderson 1954). This migration picked up steam during the 18th century as British textile technology advanced. A similar movement took place, a bit later, in the iron, engineering, and transport industries. Some famous British engineers found their way to France, such as John Holker, who became inspector general of manufacturers in France in 1756 with principal responsibility for foreign methods and foreign workers, and William Wilkinson (the brother of the ironmaster) (Harris 1998). ${ }^{20}$ Especially after the fall of Napoleon, French industrialists in the iron industry relied on British puddlers, whose expertise and skills were reflected in wages that were substantially higher than those of their French colleagues, leading to considerable resentment among local workers (Belhoste \& Woronoff 2005: 90-1).

As the relationship between France and Britain was generally tense before 1815, the flow of artisanal knowledge ran into difficulties, and flared up especially between the periods of peace between the two countries (Ballot 1923: 50-2). After 1815, however, the trickle of British artisans became a veritable flood, even if the exact number of British artisans in France is still disputed (Bensimon 2011). ${ }^{21}$ In manufacturing, British entrepreneurs would often start businesses in France and subsequently find it necessary to recruit British skilled workers to come and work in them (Bensimon 2011: 154). In addition to textiles and iron, British technicians were essential to the construction of early French railroads. But the evidence goes much further than France even though exact data are missing. The Southern Netherlands, which became the vanguard of the Industrial Revolution on the Continent, was already importing British mechanics in the 18th century. An Englishmen named Murray established a factory making nitric acid, vitriol, and iron sulphates near Brussels in 1759. The same year another Englishman named Brown received a subsidy for a textile factory

\footnotetext{
${ }^{19}$ In 1752, the French academician and industrial consultant Mignot de Montigny wrote that 'The arts never pass in written form from one nation to another, only the eyes and practice can train men in this work' (cited by Harris 1998: 550).

${ }^{20}$ In his report to the head of the French Bureau of Commerce written in 1755, Holker explained in detail how to seduce British workers to come to France, such as paying their way and making an effort to find Catholic artisans.

${ }^{21}$ Among the most notable British engineers who helped France ignite its Industrial Revolution after 1815 were Aaron Manby, a Staffordshire ironmaster, Daniel Wilson, a Scottish chemist, John Thomas, a Welsh iron master, and James Jackson, a Birmingham steelmaker (Belhoste \& Woronoff 2005: 76-7).
} 
(Lemoine 1932: 296-7). By the end of the 18th century, William Cockerill and later his son John established the leading iron foundry in the Belgian provinces at Seraing, one of the largest such enterprises in Europe (Mokyr 1976). In the Netherlands, despite the relatively modest size of the 'modern sector', English engineers played a crucial role. $^{22}$

Things were no different elsewhere on the Continent. The metallurgical industry in Prussian Silesia was built up by a Scotsman, John Baildon (1772-1846), who left Scotland at the age of 21 and spent his distinguished engineering career in that Prussian Province, followed by his son William (Szymonowicz 2007). Three skilled British workers set up and supervised the new mules established by a Saxon entrepreneur in Harthau (a suburb of the Saxon city of Chemnitz) in 1798, and another Englishman was placed in charge of another textile mill in Chemnitz a year later. The largest cotton mill on the Continent may have been the one in Pottendorf in Lower Austria, under the leadership of the Manchester mechanical engineer John Thornton (1771-1847) and his brothers (Henderson 1954: 143, 194). Most striking was the career of a Welsh engineer, John Hughes (1814-89), who ended up in eastern Ukraine in 1870, bringing along about a hundred Welsh ironworkers to start one of the most successful industrial enterprises of Imperial Russia in a town that was eventually named after him (Yuzhovka, today Donetsk). Coal mines in the Ruhr had names like Hibernia and Shamrock, evidence of the role played in their development by Irish engineers, most notably William Thomas Mulvany (1806-85) and the Durham engineer he recruited, William Coulson (Henderson 1954: 184-5).

What we can conclude from these facts is that Britain may have had a comparative advantage in highly skilled labour rather than in inventions as such. It imported a large number of technological ideas from the Continent, such as chlorine bleaching, soda-making, the wet-spinning process for linen, food canning, and quite a few others. Yet, at least until 1850, it was British engineers and mechanics who knew how to install and operate the new machinery, worked out the bugs, tweaked them to adapt to local environments, and scaled them up into large and - at least sometimesprofitable mills. These mechanics were the most important resource responsible for Britain's leading position. They were quite different from the intellectuals and the applied mathematicians who also should be counted as part of the UTHC population. Their knowledge was tacit, and their main assets were a technical savoir faire based on intuition, training, experience, and dexterity.

${ }^{22}$ Thomas Ainsworth, a scion of a Lancashire family of textile industrialists, assisted by his brother, was the founder of the textile industries in the eastern province of Overijssel in the 1830s (Lintsen 1995: 64-6). In Haarlem, a cotton factory was set up by another Englishman, Thomas Wilson. 
The superiority of British skills before and during the heyday of the Industrial Revolution is also attested by the continuous flow of foreigners to Britain trying to study British skills and production methods. While fundamental inventions moved in both directions, industrial espionage in various forms was almost entirely carried out by Continental engineers and mechanics, trying to learn the secrets of British industrial competence. This was true above all for France, which conducted systematic industrial espionage in Britain for much of the 18th century (Harris 1998). But others, especially Germans, travelled to Britain as well. Johann Gottfried Brügelmann had actually been an employee of Arkwright's Cromford Mill, and when he established his own plant in Ratingen (near Düsseldorf) he appropriately named it Kromford (1794). Karl Friedrich Bernhard, who established the spinning mules near Chemnitz run by William Whitefield of Halifax in 1799 had himself worked in Manchester. Lieven Bauwens, the Flemish entrepreneur who famously smuggled out a prototype of a spinning mule in 1799, had been sent by his father to work in Britain for three years, where his interest in the cotton industry was aroused and where he absorbed the latest technical advances. ${ }^{23}$

At times, Continental inventors actually travelled to England to have their contraptions built by British craftsmen or using British materials. The best known of those was the Geneva-born Aimé Argand, the inventor of the eponymous lamp, who decided to have his device built in England, where he teamed up with the top engineering firm in the world, Boulton and Watt. His lamp eventually became a technological (if not a commercial) success. Many other foreign inventors active in Britain could be listed here (see Mokyr 2009: 113-14). As so often happens, people travelled for a variety of reasons. ${ }^{24}$ What is beyond doubt was that industrial espionage was by and large a one-way street and, despite France's efforts in sending some accomplished people to England, the effectiveness of such espionage was limited. As John R. Harris concludes in his magnum opus on the subject: 'in the end it was imported skills in manufacture, assembly and operation which were necessary for success' (Harris 1998: 561).

\footnotetext{
${ }^{23}$ The Manchester mechanic James Kenyon, who had assisted Bauwens in acquiring the illegal machinery (and whose daughter eventually married Bauwens), accompanied him back to Ghent (with five additional skilled English artisans) and helped him run his business.

${ }^{24}$ The French engineer Marc Isambard Brunel fled France for political reasons, but in England he teamed up with the mechanical engineer Henry Maudslay and the entrepreneur Samuel Bentham to build the famed block-making machinery in Portsmouth.
} 


\section{The roots of British technological competence}

There is no single one-line explanation for the high competence of British artisans. Human capital is not an undifferentiated mass, where 'more is better' applies. British aristocrats invested in the human capital of their offspring, but usually taught them the skills of a life of sophisticated leisure (Doepke \& Zilibotti 2008). Latin, fencing, music, and hunting may have been proper gentlemanly activities, but they did little for mechanisation. The same was true mutatis mutandis for Jewish sages in medieval Europe: learned, sophisticated, deeply intellectual, they were the very embodiment of human capital, yet their contributions to technology and other forms of useful knowledge were at best marginal. What mattered for the Industrial Revolution was above all the kind of human capital that was not taught at school, but the tacit yet indispensable artisanal competence that was passed through imitation and direct personal contact.

In 17th- and 18th-century Britain, the transmission of human capital among the artisanal classes became increasingly effective, and the skills of the very best artisans were sophisticated as well as nimble. As the economy posed increasing challenges to existing human capital from both the demand and the supply side, the training system of artisans and engineers responded elastically and was able to produce the mechanics that the Industrial Revolution needed. Of course, this was not a painless process: British entrepreneurs complained bitterly about having their skilled workers poached by their competitors (or foreigners) and often had to put up with wilful members of the labour aristocracy.

There are three basic types of explanations of the British advantage in high-skill artisans. One was a demand-side factor. There is considerable evidence that by 1700 or so British income per capita was already considerably above subsistence and that the Malthusian threat had subsided. Moreover, income distribution was less unequal than elsewhere in Europe, creating a substantial middle class, which purchased high-quality goods. Optical and musical instruments, clocks and watches, high-end furniture, cutlery, and other steel products were included in this middle-class luxury consumption, increasing the demand for skilled workers. ${ }^{25}$ But elsewhere in the economy demand mattered as well: the coal-mining sector had grown rapidly in the centuries before the Industrial Revolution, in part for industrial uses but above all for home heating, as more and more people could afford to heat their homes with more efficient fuels. The mining sector was a classic 'focusing device' in Nathan Rosenberg's (1976) famous terminology, because it posed major technological challenges,

${ }^{25}$ Steel's capacity for a high level of polish made it desirable to the toy industry. One of the prized luxuries of the 18th century was a watch-chain made of steel (Evans \& Withey 2012: 545). 
the really hard problems of dealing with 'forces much greater than those normally encountered in technics' (Cardwell 1972: 74). Another source of demand was defence. Naval ironware for the Royal Dockyard at Portsmouth, such as hoops and anchors, was the main target of opportunity for Henry Cort, the inventor of the puddling and rolling process (1785), and his partner Richard Crawshay had been a former ordnance maker for the British state (Evans 2005: 24-5). Moreover, perhaps one of the most advanced and sophisticated production facilities in the world was the Portsmouth naval block-making factory, designed by two of the finest engineers of the age, Henry Maudslay and Marc Isambard Brunel. Yet military demand by itself could not have been the main factor that set Britain apart, as Continental nations had navies too, as well as much larger armies.

It is at this juncture that the Atlantic economy, based on slaves and the trade in the colonial crops they laboured to produce, is thought by many to have played an important role. American raw cotton cultivation - wholly dependent on slave labourbecame an indispensable component of the British textile sector, and without it the Industrial Revolution would have played out quite differently. Cotton textiles were needed to clothe the colonists and their slaves of the American colonies both in the regions in what became the United States and in the Caribbean, and this source of demand more or less guaranteed market-stimulated progress in the cotton industry (Riello 2013: 150). Less well known is one of the most significant but (until recently) unsung breakthroughs of the Industrial Revolution, namely the use of copper sheathing on ocean-going vessels, which was directly connected to the slave trade (Solar \& Rönnbäck 2015, Kelly et al. 2021b), a major improvement in shipbuilding technology. Separately, Zahedieh (2021) has stressed the role of the Atlantic economy as a rapidly expanding export market for wrought copper, which was an important input in sugar processing. ${ }^{26}$ Inikori (2002: 467-71) has stressed the export markets in West Africa for guns, copper products, and 'toys' among other things.

At the end of the day, however, it remains a difficult task to demonstrate Eric Williams's (1944) argument that the slave economy and Atlantic trade were critical factors in the Industrial Revolution despite its size (Eltis \& Engerman 2000, McCloskey 2010: 197-239, Rönnbäck 2018). Such increases in demand, whether colonial or domestic, in and of themselves would have done little to drive the technological

\footnotetext{
${ }^{26}$ Nuala Zahedieh (13) notes that 'Cornish copper mining supported the development of an internationally renowned engineering sector and nurtured metalworking and machine-making skills that had applications well beyond the copper sector and underpinned Britain's competitive advantage in Europe.' Cornish engineers such as Richard Trevithick and Arthur Woolf played key roles in the second stage of steamengine development and the Cornish engineering firm of John Harvey \& Co was one of the most advanced and sophisticated manufacturers of machinery in the age of the Industrial Revolution. For details about technological advances in this sector, see Mokyr (2009: 131-2).
} 
breakthroughs of the Industrial Revolution had there been no prior high level of engineering competence. Some of the more striking innovations in the Cornish copper industry occurred before the rapid expansion of sugar production in the Caribbean. British mechanical ingenuity was behind the supply response to rising demand, but the primary causality was from human capital and low prices to exports. What was needed was a training system for talented and dexterous people with the drive and capability to become top-rated mechanics.

About the source of the supply of skilled artisans, there can be little doubt: technical competence was a form ofhuman capital produced within the system itself, through apprenticeship relations. Although a few of the best mechanics and engineers were to some extent auto-didacts, the vast bulk of them were apprenticed to masters, often more than one. The structure of the apprenticeship market in pre-Industrial Revolution has in recent years been shown to have been unusually effective and flexible (Wallis 2008, Leunig et al. 2011, De la Croix et al. 2018, Ben Zeev et al. 2017, Mokyr 2019).

It is at this stage of the argument that institutions truly mattered. Apprenticeship contracts for obvious reasons were highly problematic and incomplete, with myriad possibilities for cheating, shirking, and other forms of opportunistic behaviour. For most of history societies have had to come up with institutional solutions that at least ensured that practical knowledge would be transferred intergenerationally. In many ways, Britain before the Industrial Revolution developed a well-working and agile system in which the contract between master and apprentice normally worked well, and in which guilds played a fairly minor role. ${ }^{27}$ This was in contrast to much of Europe, where contract enforcement was still largely the responsibility of guilds with all the disadvantages thereof. In England contracts were enforced in large part through self-enforcing mechanisms such as reputation.

When serious disputes between master and apprentice arose, third-party enforcement was needed. There were many variations on the basic theme that some respectable local third party was needed to arbitrate and settle out of court the frequent disputes that arose between master and apprentice (Davies 1956). Going to a formal court of law such as a Justice of the Peace was possible but, given the cost and uncertainty of the outcome and the long duration of lawsuits, it must have been a pis aller, though some courts, such as the Lord Mayor's Court in London, employed speedier and less costly arbitration and more balanced reconciliation procedures

\footnotetext{
${ }^{27}$ The need for regulation was recognised by the state by passing the famous Statute of Artificers and apprentices in 1563, which stipulated many of the parameters of the relationship. Yet the Statute, especially in the 18th century, was rarely strictly enforced and can be seen as advisory more than binding, exemplifying the flexibility of the apprenticeship system (Davies 1956). The Statute was abolished in 1814, yet the apprenticeship institution survived and even thrived in the 19th century.
} 
(Wallis 2012: 793). Much of the arbitration between the master and his apprentice and his family must have taken place in the 'shadow of the law' suggested by scholars in law and economics. While this system was far from perfect by some ideal standard, it worked better than almost anywhere in Europe. The net result was not only that Britain developed a skill superiority but also that, as the demand for high-competence craftsmen rose after 1750, there was little or no rise in the skill premium (Clark 2005, Van Zanden 2009).

Finally, one simple explanation of the British advantage in skilled labour derived from the higher overall quality of the British labour force compared to the Continent, in large part because of the relatively high living standards and good nutrition enjoyed by the British population on the eve of the Industrial Revolution. British workers were taller and by most accounts stronger than Continental ones (Kelly et al. 2014, Baumard 2019). As Nicolas Baumard points out, a workforce that did not grow up in grinding poverty would be more likely to take risks, be more resourceful and cooperative, and more likely to show initiative. While these characteristics were not identical to skills and technical aptitude, they were in all likelihood correlated. ${ }^{28}$ Most striking, however, is the observation that, if we are able to define an attribute such as mechanical competence that is distributed over the population in some kind of symmetrical distribution, even small differences in the mean will lead to a much amplified gap in the density in the upper tail. ${ }^{29}$ Hence, the differences in working-class diet, health, and living conditions between Britain and the Continent may have driven a far larger difference in UTHC.

\section{The rise and fall of technological leadership}

It is important to stress that the practical knowledge that the British elite artisans excelled in was by and large informal, tacit, and intuitive. Some of it was, of course, based on the work of natural philosophers of a more practical bent than Smith and Hume were thinking about, which had filtered down to the workshops through various intermediate channels. The Industrial Revolution can then be seen as an example of a deep complementarity of codified formal knowledge and tacit knowledge mostly in the form of mechanical and chemical competence.

\footnotetext{
${ }^{28}$ On the other hand, there seems to have been little correlation between technical ability and managerial or business competence, and many of the great engineers and inventors failed financially. Some of those who did the best were engineers, such as James Watt and Matthew Murray, who teamed up with able managers. ${ }^{29}$ For example, in a normal distribution with $\mu=100$ and $s=10$, a small difference of 1 per cent in the mean would lead to a 50 per cent difference in the density of the tail above $4 s$. It is clear that 'ability' and 'competence' are multidimensional attributes, and that representing them as the distribution of a single variable is a simplification.
} 
As noted above, the concept of comparative advantage can be deployed here to explain the difference between Britain and its Continental neighbours. While Britain had a comparative advantage in tacit knowledge and the 'tricks' of the trade, acquired through informal and personal channels, such as apprenticeship and personal knowledge, the European Continent had a comparative advantage in formal and codified knowledge. This difference can be already noticed before the Industrial Revolution: the writings of the French academician and polymath René Réaumur on steel, egg incubation, and apiculture were all translated into English. The most extensive technical book on coal and collieries was written by a French physician, Jean-François C. Morand (1768-79). While England had the most extensive copper-smelting industry in 18th-century Europe, economic historians depend on Continental sources for its description (Harris 1974: 97). Perhaps the largest compilation of technical descriptions of manufacturing and related activities was contained in the enormous ( 80 volume) collection of industrial handbooks published by the French Académie before the Revolution, namely the Description des Arts et Métiers. Even in civil engineering, where British superiority was among the most pronounced, French texts dominated. ${ }^{30}$ The English produced and engineered; the French wrote about it. Both nations had been part and parcel of the Industrial Enlightenment, and both realised that knowledge was the key to economic progress; but there were nuances in how they were going to carry out this programme.

In the longer run, however, tacit knowledge had to make room for more formal and scientifically based approaches. In the 18th century, formal chemistry, physics, biology, and engineering science affected industry in a spotty way. In the 19th century, as industry came to depend increasingly on more experimental and mathematical methods, formal advanced education increasingly became of central importance in sustained innovation. It was here that the European Continent had the advantage.

By the middle of the 19th century, when British technological superiority was perhaps at its peak, it was already sensed that what had served the economy so well in the late 18th century and in the first third of the 19th, may not work so well in the coming decades. Charles Babbage had already made this point in about 1830, when he stressed the growing dependence of industrial progress on science. ${ }^{31}$ Yet he clearly was

\footnotetext{
${ }^{30}$ Among the notable engineering texts were 'the best contemporary account of the steam engine' written by Gaspard de Prony (1794), the widely read and translated Essay sur la Composition des Machines published in 1808 by Agustín de Betancourt and José Maria Lanz, and J.P.N. Hachette's Traité Elémentaire des Machines (1811). See Cardwell (1994: 205).

${ }^{31}$ 'It is impossible not to perceive that arts and manufactures of the country are intimately connected with the progress of the severer sciences; and that, as we advance in the career of improvement every step requites ... for this connection should be rendered more intimate ... the efforts for the improvements of its manufactures ... must arise from the exertions of those most skilled in the theory of the arts' (Babbage 1835: 379).
} 
deeply concerned about Britain's alleged neglect of science compared with its Continental competitors. (Babbage 1830). One of the best known of those concerns was expressed by the chemist Lyon Playfair twenty years after Babbage in a famous lecture to the 1851 Crystal Palace Exhibition, pointing out that industry must in future be supported, not by a competition of local advantages, but by competition of intellect. All European nations, except England, have recognized this fact.' And he added, with some exaggeration, that 'Industry, to which this country owes her success among nations, has never been raised to the rank of a profession ... science, which has raised her to this eminence is equally unrecognized' (Tallis 1852: vol. 2, 194, 198).

A reconsideration of British leadership along the lines suggested above would confirm that it rested on a temporary advantage and that sooner or later the rest of Europe would catch up. Underneath the Industrial Revolution and the realisation of the Baconian programme lay a pan-European cultural movement, the Enlightenment. Enlightenment thought stressed the importance of useful knowledge to economic progress. Other nations observed Britain's achievement and did what they could to catch up, first of all employing British mechanics and engineers to instruct their own. They also proceeded to establish the polytechnics and engineering schools that trained the kind of Upper Tail Human Capital that was increasingly needed for sectors such as electricity, steel, communications, advanced steam power, and chemicals. Britain was late in establishing such schools (Wrigley 1986).

Finally, the emphasis on skills and competence proposed here does not preclude many of the other explanations proposed for Britain's precocity. Two of the most influential interpretations are the 'geographical school' that regards British location and resources as the primary advantage and the school that emphasises institutions and politics as the decisive difference. Clearly Britain's location as an island encouraged industries that were clustered around the maritime sector, from shipbuilding and gun-making to high-precision navigational instruments and copper-sheathing. Coal mining, as already noted, spurred a host of innovations, not just mechanical but also those related to prospecting through the highly trained coal-viewers. Moreover, Britain's location meant that coastal shipping made for highly integrated markets, leading to regional specialisation. Regional specialisation in turn raised the returns on investment in training and skills in those areas specialising in production relying on skills, and thus raised their supply exactly where they were most needed (Kelly et al. 2021a).

A similar argument holds for the 'institutional school'. As far as institutions are concerned, we have already noted Britain's weak guilds, which actually may have made the pivotal institution of apprenticeship more effective (Ogilvie 2019). But beyond that, Britain was relatively speaking a land of law and order in which contracts were enforced and property was more or less respected, and one in which social norms 
and bourgeois ethics encouraged 'gentleman-like' behaviour (discouraging opportunism). Indeed, one can speak of Britain having a 'civil economy' in which reputation mechanisms ensured that most actors would be cooperative (Mokyr 2008). Britain also had an effective fiscal system and no internal tariffs or tolls (which again contributed to market integration). It is important to stress that these institutions were not designed from the outset to raise the quality of Upper Tail Human Capital and that what we describe above was the unintended and unplanned consequences of local actions. What we observe, as so often in history, is that outcomes were determined by 'emergent properties' - complex social structures that emerged from lower-level and low-complexity economic interactions.

All in all, in the economic history of the world, with some poetic licence Britain can be regarded in the same way as the land of Israel is regarded in the history of Christianity. It is where it all started, and for good historical reasons. From there, it spread to faraway regions, and over time its own role in what it generated became modest. But, despite these historical vicissitudes, British economic history will continue to fascinate scholars as the Holy Land of Industrialism.

\section{Acknowledgements}

This essay is in part based on joint work with Morgan Kelly, Cormac Ó Gráda, Assaf Sarid, and Karine van der Beek. I alone, however, am responsible for its content. I am indebted to Professors Kelly and Ó Gráda and to Professor Maxine Berg for helpful suggestions on an earlier draft and to Michael Giordano for excellent research assistance.

\section{References}

Amis, K. (1976), The Alteration (London, Jonathan Cape).

Babbage, C. (1830), Reflections on the Decline of Science in England (London, Printed for B. Fellowes).

Babbage, C. (1835), On the Economy of Machinery and Manufactures, 4th edn enlarged (London, C. Knight).

Ballot, C. (1923), L'Introduction du Machinisme dans l'Industrie Française (Paris, F. Rieder).

Baumard, N. (2019), 'Psychological Origins of the Industrial Revolution', Behavioral and Brain Sciences, 42(e189): 1-63. https://doi.org/10.1017/S0140525X19001183

Belhoste, J.-F. \& Woronoff, D. (2005), 'The French Iron and Steel Industry During the Industrial Revolution', in C. Evans \& G. Rydén (eds) The Industrial Revolution in Iron (Aldershot, Ashgate), 75-94. https://doi.org/10.4324/9781315238999-5

Bensimon, F. (2011), 'British Workers in France, 1815-1848', Past and Present, 213: 147-89. https://doi.org/10.1093/pastj/gtr015 
Ben Zeev, N,. Mokyr, J. \& van der Beek, K. (2017), 'Flexible Supply of Apprenticeship in the British Industrial Revolution', Journal of Economic History, 77: 208-50. https://doi.org/10.1017/S0022050717000043

Berg, M. (2007), 'The Genesis of Useful Knowledge', History of Science, 45(2): 123-34. https://doi.org/10.1177/007327530704500201

Bertucci, P. (2017), Artisanal Enlightenment: Science and the Mechanical Arts in Old Regime France (New Haven, CT, and London, Yale University Press). https://doi.org/10.12987/yale/9780300227413.001.0001

Cardwell, D.S.L. (1972), Turning Points in Western Technology (New York, Neale Watson, Science History Publications).

Cardwell, D.S.L. (1994), The Fontana History of Technology (London, Fontana).

Christie, J.R.R. (2018), 'Chemical Glasgow and its Entrepreneurs', in L.L. Roberts \& S. Verrett (eds) Compound Histories: Materials, Governance and Production, 1760-1840 (Leiden, Brill), 311-32. https://doi.org/10.1163/9789004325562_015

Clark, G. (2005), 'The Condition of the Working Class in England, 1209-2004', Journal of Political Economy, 113(6): 1307-40. https://doi.org/10.1086/498123

Cookson, G. (2018), The Age of Machinery: Engineering in the Industrial Revolution, 1770-1850 (London, Boydell and Brewer). https://doi.org/10.1017/9781787442382

Crafts, N.F.R. (1977), 'Industrial Revolution in Britain and France: Some Thoughts on the Question "Why Was England First?", Economic History Review, 30: 429-41. https://doi.org/10.2307/2594877

Croarken, M. (2002), 'Providing Longitude for All: The Eighteenth Century Computers of the Nautical Almanac', Journal of Maritime Research, 9: 1-22. https://doi.org/10.1080/21533369.2002.9668324

Daumas, M. (1972), Scientific Instruments of the Seventeenth and Eighteenth Centuries and their Makers (London, SAGE).

Davids, K. (2008), The Rise and Decline of Dutch Technological Leadership (Leiden and Boston, MA, Brill), 2 vols. https://doi.org/10.1163/ej.9789004168657.i-634

Davies, M.G. (1956), The Enforcement of English Apprenticeship: A Study in Applied Mercantilism, 1563-1642 (Cambridge, MA, Harvard University Press).

De la Croix, D., Doepke, M. \& Mokyr, J. (2018), 'Clans, Guilds, and Markets: Apprenticeship Institutions and Growth in the Pre-industrial Economy', Quarterly Journal of Economics, 133(1): 1-70. https://doi.org/10.1093/qje/qjx026

Dittmar, J.E. \& Meisenzahl, R.R. (2020), 'Public Goods Institutions, Human Capital, and Growth: Evidence from German History', The Review of Economic Studies, 87(2): 959-96. https://doi.org/10.1093/restud/rdz002

Doepke, M. \& Zilibotti, F. (2008), 'Occupational Choice and the Spirit of Capitalism', Quarterly Journal of Economics, 123(2): 747-93. https://doi.org/10.1162/qjec.2008.123.2.747

Eltis, D. \& Engerman, S.L. (2000), 'The Importance of Slavery and the Slave Trade to Industrializing Britain', The Journal of Economic History, 60(1): 123-44.

Engels, F. (1892) [1845], The Condition of the Working Class in England in the Year 1844 (London, Schwan-Sonnenschein).

Epstein, S.R. (2008), 'Craft Guilds, the Theory of the Firm, and the European Economy, 1400-1800', in S.R. Epstein \& M. Prak (eds) Guilds, Innovation and the European Economy, 1400-1800 (Cambridge, Cambridge University Press), 52-80. https://doi.org/10.1017/CBO9780511496738.003

Evans, C. (2005), 'The Industrial Revolution in Iron in the British Isles', in C. Evans \& G. Rydén (eds) The Industrial Revolution in Iron (Aldershot, Ashgate), 15-27. https://doi.org/10.4324/9781315238999-2 
Evans, C. \& Withey, A. (2012), 'An Enlightenment in Steel? Innovation in the Steel Trades of Eighteenth-century Britain', Technology and Culture, 53(3): 533-60. https://doi.org/10.1353/tech.2012.0116

Fairbairn, W. (1861), Treatise on Mills and Millwork, Part I (London, Longman, Green, Longman and Roberts).

Ford, H. [1922] (2013), The Expanded and Annotated My Life and Work, ed. W.A. Levinson (Boca Raton, FL, CRC Press).

Fox, R. (2004), 'William Irvine', Oxford Dictionary of National Biography (Oxford, Oxford University Press).

Gillispie, C.C. (2004), Science and Polity in France: The Revolutionary and Napoleonic Years (Princeton, NJ, Princeton University Press). https://doi.org/10.1515/9781400865314

Goldstone, J.A. (2006), 'Europe's Peculiar Path,' in P.E. Tetlock, R.N. Lebow \& G. Parker (eds) Unmaking the West: 'What-if' Scenarios that Rewrite World History (Ann Arbor, MI, University of Michigan Press), 168-96.

Goldstone, J.A. (2009), Why Europe? The Rise of the West in World History, 1500-1850 (Boston, MA, McGraw-Hill).

Hanlon, W. (2020), 'The Rise of the Engineer: Inventing the Professional Inventor During the Industrial Revolution', unpublished working paper.

Harley, C.K. (2015), 'Slavery, the British Atlantic Economy, and the Industrial Revolution', in A.B. Leonard \& D. Pretel (eds) The Caribbean and the Atlantic World Economy: Circuits of Trade, Money and Knowledge, 1650-1914 (New York, Palgrave Macmillan), 161-83. https://doi.org/10.1057/9781137432728_8

Harris, J.R. (1974), 'The Rise of Coal Technology', Scientific American, 231(2): 92-7. https://doi.org/10.1038/scientificamerican0874-92

Harris, J.R. (1998), Industrial Espionage and Technology Transfer: Britain and France in the Eighteenth Century (Aldershot, Ashgate).

Hartwell, R.M. (1990), 'Was There an Industrial Revolution?', Social Science History, 14: 567-76. https://doi.org/10.1017/S0145553200020940

Heilbron, J.L. (1990), 'Introductory Essay', in T. Frängsmyr, J.L. Heilbron \& R.E. Rider (eds) The Quantifying Spirit in the 18th Century (Berkeley, CA, University of California Press), 1-23.

Henderson, W.O. (1954), Britain and Industrial Europe, 1750-1870; Studies in British Influence on the Industrial Revolution in Western Europe (Liverpool, Liverpool University Press). https://doi.org/10.2307/2551743

Hoffman, P.T. (2015), Why Did Europe Conquer the World? (Princeton, NJ, Princeton University Press). https://doi.org/10.1515/9781400865840

Howes, A. (2017), 'The Relevance of Skills to Innovation During the British Industrial Revolution, 1547-1851', unpublished working paper.

Hume, D. [1742] (1985), 'Of the Rise and Progress of the Arts and Sciences', in David Hume, Essays: Moral, Political and Literary, ed. E.F. Miller (Indianapolis, IN, Liberty Fund), 111-37.

Inikori, J.E. (2002), Africans and the Industrial Revolution in England: A Study in International Trade and Economic Development (Cambridge, Cambridge University Press). https://doi.org/10.1017/CBO9780511583940

Jacob, M.C. (2014), The First Knowledge Economy (Cambridge, Cambridge University Press).

Kelly, M. \& Ó Gráda, C. (2017), 'Adam Smith, Watch Prices, and the Industrial Revolution', Quarterly Journal of Economics, 131(4): 1727-52. https://doi.org/10.1093/qje/qjw026

Kelly, M., Mokyr, J. \& Ó Gráda, C. (2014), 'Precocious Albion: A New Interpretation of the British Industrial Revolution', Annual Review of Economics, 6: 363-91.

https://doi.org/10.1146/annurev-economics-080213-041042 
Kelly, M., Mokyr, J. \& Ó Gráda, C. (2021a), 'The Mechanics of the Industrial Revolution', unpublished.

Kelly, M., Ó Gráda, C. \& Solar, P. (2021b), 'Safety at Sea During the Industrial Revolution,' Journal of Economic History, 81(1): 239-75. https://doi.org/10.1017/S0022050720000595

Lazonick, W. (1979), 'Industrial Relations and Technical Change: The Case of the Self-acting Mule', Cambridge Journal of Economics, 3(3): 231-62.

Lemoine, R.J. (1932), 'Les étrangers et la formation du capitalisme en Belgique', Revue d'Histoire Economique et Sociale, 20: 252-336.

Leonard A.B. \& Pretel, D. (eds) (2015), The Caribbean and the Atlantic World Economy: Circuits of Trade, Money and Knowledge, 1650-1914 (New York, Palgrave Macmillan).

Leunig, T., Minns, C. \& Wallis, P. (2011), 'Networks in the Premodern Economy: The Market for London Apprenticeships, 1600-1749', Journal of Economic History, 71(2): 413-41. https://doi.org/10.1017/S0022050711001586

Lintsen, H.W. (ed.) (1995), Techniek in Nederland: Vol. VI, De wording van een Moderne Samenleving, 1800-1890 (Zutphen, Walburg Pers).

MacLeod, C. \& Nuvolari, A. (2009), 'Glorious Times: The Emergence of Mechanical Engineering in Early Industrial Britain, c. 1700-1850’, Brussels Economic Review, 52: 215-37.

McCloskey, D.N. (2010), Bourgeois Dignity: Why Economics Can't Explain the Modern World (Chicago, IL, University of Chicago Press). https://doi.org/10.7208/chicago/9780226556666.001.0001

McCloskey, D.N. (2021), 'How Growth Happens', presented to the Cato Conference, 31 March, unpublished.

Meisenzahl, R.R. \& Mokyr, J. (2012), 'The Rate and Direction of Invention in the British Industrial Revolution: Incentives and Institutions', in S. Stern \& J. Lerner (eds) The Rate and Direction of Innovation (Chicago, IL, University of Chicago Press), 443-79. https://doi.org/10.7208/chicago/9780226473062.003.0013

Mokyr, J. (1976), Industrialization in the Low Countries, 1795-1850 (New Haven, CT, and London, Yale University Press).

Mokyr, J. (2008), 'The Institutional Origins of the Industrial Revolution', in E. Helpman (ed.) Institutions and Economic Performance (Cambridge, MA, Harvard University Press), 64-119.

Mokyr, J. (2009), The Enlightened Economy (New York, CT, and London, Yale University Press).

Mokyr, J. (2019), 'The Economics of Apprenticeship', in M. Prak \& P. Wallis (eds) Apprenticeship in Early Modern Europe (Cambridge, Cambridge University Press), 20-43. https://doi.org/10.1017/9781108690188.002

Mokyr, J., Sarid A. \& van der Beek, K. (2021), 'The Wheels of Change: Technology Adoption, Millwrights, and the Persistence in Britain's Industrialization', unpublished.

Morand, J.-F.C. (1769-78) [2012], L'art d'exploiter les mines de charbon de terre. Du charbon de terre et de ses mines, repr. edn (Paris, Hachette).

Ogilvie, S. (2019), The European Guilds: An Economic Analysis (Princeton, NJ, Princeton University Press).

Ó Grada, C. (2016), 'Did Science Cause the Industrial Revolution?', Journal of Economic Literature, 54(1): 224-39. https://doi.org/10.1257/jel.54.1.224

Riello, G. (2013), Cotton: The Fabric that Made the Modern World (Cambridge, Cambridge University Press). https://doi.org/10.1017/CBO9780511706097

Rönnbäck, K. (2018), 'On the Economic Importance of the Slave Plantation Complex to the British Economy during the Eighteenth Century: a Value-added Approach', Journal of Global History, 13: 309-27. https://doi.org/10.1017/S1740022818000177

Rosenberg, N. (1976), Perspectives on Technology (Cambridge, Cambridge University Press).

Simond, L. [1815] (1968), An American in Regency England: The Journal of a Tour in 1810-1811, ed. C. Hibbert (London, The History Book Club). 
Skempton, A. (ed.) (2002), Biographical Dictionary of Civil Engineers, 1500-1830 (London, Thomas Telford for the Institution of Civil Engineers).

Smiles, S. [1863] (1883), Ironworkers and Toolmakers (Chicago, Belford Clarke \& Co.).

Smith, A. [1762-1763] (1978), Lectures on Jurisprudence, ed. R.L. Meek (Oxford, Oxford University Press).

Solar, P.M. \& Rönnbäck, K. (2015), 'Copper Sheathing and the British Slave Trade', Economic History Review, 68(3): 806-29. https://doi.org/10.1111/ehr.12085

Squicciarini, M.P. \& Voigtländer, N. (2015), 'Human Capital and Industrialization: Evidence from the Age of Enlightenment', Quarterly Journal of Economics, 130(4): 1825-83.

https://doi.org/10.1093/qje/qjv025

Szymonowicz, J. (2007), 'A Scotsman in Silesia', Warsaw Voice, 28 March. https://web.archive.org/ web/20071111073309/http://www.warsawvoice.pl/view/14399.

Tallis, J. (1852), Tallis's History and Description of the Crystal Palace, and the Exhibition of the World's Industry in 1851 (London and New York, J. Tallis).

Thébauld-Sorger, M. (2018), 'Capturing the Invisible: Heat, Steam, and Gases in France and Great Britain, 1750-1800', in L.L. Roberts \& S. Verrett (eds) Compound Histories: Materials, Governance and Production, 1760-1840 (Leiden, Brill), 85-105. https://doi.org/10.1163/9789004325562_005

Van Zanden, J.L. (2009), The Road to the Industrial Revolution: Institutions and Human Capital Formation in Europe in Global Perspective, 1000-1800 (Leiden, Brill). https://doi.org/10.1163/ej.9789004175174.i-346

Vries, P.H.H. (2013), The Escape from Poverty (Vienna, Vienna University Press).

Wallis, P. (2008), 'Apprenticeship and Training in Premodern England', Journal of Economic History, 68: 832-61. https://doi.org/10.1017/S002205070800065X

Wallis, P. (2012), 'Labor, Law, and Training in Early Modern London: Apprenticeship and the City's Institutions', Journal of British Studies, 51(4): 791-819. https://doi.org/10.1086/666731

Williams, E. (1944), Capitalism and Slavery (Chapel Hill, NC, University of North Carolina Press). Wrigley, J. (1986), 'Technical Education and Industry in the Nineteenth Century', in B. Elbaum \& W. Lazonick (eds) The Decline of the British Economy (Oxford, Clarendon Press), 162-88.

Zahedieh, N. (2021), 'Eric Williams and William Forbes: Copper, Colonial Markets, and Commercial Capitalism', Economic History Review, forthcoming. https://doi.org/10.1111/ehr.13050

To cite the article: Joel Mokyr (2021), “The Holy Land of Industrialism”: rethinking the Industrial Revolution', Journal of the British Academy, 9: 223-247.

DOI https://doi.org/10.5871/jba/009.223

Journal of the British Academy (ISSN 2052-7217) is published by

The British Academy, 10-11 Carlton House Terrace, London, SW1Y 5AH

www.thebritishacademy.ac.uk 